\title{
OPEM
}

www.opem.org

Oriental Pharmacy and Experimental Medicine 2008 8(4), 440-447

DOI 10.3742/OPEM.2008.8.4.440

\section{Panax Ginseng inhibited HIF-1a activation and inflammatory cytokine in HMC-1 cells activated by phorbol myristate acetate and A23187}

\author{
In-Young Choi ${ }^{1}$, Hyun-Ja Jeong ${ }^{2}$, Hyo-Jin $\mathrm{An}^{3}$, Tae-Hee Kang ${ }^{3}$, Chul-Won $\mathrm{Zo}^{3}$, Bong-Keun Song ${ }^{4}$, \\ Eun-Jeong Park ${ }^{4}$, Eun-Cheol Kim ${ }^{5}$, Jae-Young $\mathrm{Um}^{3}$, Hyung-Min $\mathrm{Kim}^{3}$, and Seung-Heon Hong ${ }^{1, *}$ \\ ${ }^{I}$ Department of Oriental Pharmacy, College of Pharmacy, Wonkwang University, Iksan, Jeonbuk, 570-749, Republic of \\ Korea; ${ }^{2}$ Biochip Research Center, Hoseo University 165, Sechul-ri, Baebang-myun, Asan, Chungnam, 336-795, \\ Republic of Korea; ${ }^{3}$ College of Oriental Medicine, Kyung Hee University, 1 Hoegi-Dong, Dongdaemun-Gu, Seoul, 130- \\ 701, Republic of Korea; ${ }^{4}$ College of Oriental Medicine, Wonkwang University, Iksan, Jeonbuk, 570-749, Republic \\ of Korea; ${ }^{5}$ Department of Oral and Maxillofacial Pathology, College of Dentistry, Wonkwang University, Iksan, \\ Republic of Korea
}

Received for publication October 08, 2008; accepted November 12, 2008

\begin{abstract}
SUMMARY
This study investigated the role of Panax ginseng (PG) on the phorbol myristate acetate (PMA) + calcium ionophore A23187-induced hypoxia-inducible factor- $1 \alpha$ (HIF-1 $\alpha$ ) activation, phosphorylation of the extracellular signal-regulated kinase (ERK), and inflammatory cytokine production from the human mast cell line, HMC-1. HIF-1 $\alpha$ and phosphorylation of ERK were observed by Western blotting. The inflammatory cytokine production was determined by enzyme-linked immunosorbent assay. PG inhibited the PMA+A23187-induced HIF-1 $\alpha$ expression and the subsequent production of vascular endothelial growth factor. In addition, PG suppressed PMA + A23187-induced phosphorylation of ERK. We also show that the increased cytokines interleukin (IL)-1 $\beta$, IL-6, and tumour necrosis factor- $\alpha$ level was significantly inhibited by treatment of PG. In the present study, we report for the first time that PG is an inhibitor of HIF-1 $\alpha$ and cytokines on the mast cell-mediated inflammatory responses.
\end{abstract}

Keywords: panax ginseng; hypoxia-inducible factor- $1 \alpha$; extracellular signal-regulated kinase; cytokines; mast cells

\section{INTRODUCTION}

The transcription factor, hypoxia-inducible factor-1 (HIF-1) is associated with numerous physiological and pathological processes that include tumorigenesis, vascular remodeling, inflammation, and hypoxia/ ischemiarelated tissue damage (Semenza, 2004). HIF-1 is a heterodimeric basic helix-loop-helix-

\footnotetext{
*Correspondence: Seung-Heon Hong, Department of Oriental Pharmacy, College of Pharmacy, Wonkwang University, Iksan, Jeonbuk, 570-749, Republic of Korea. E-mail: jooklim@wonkwang.ac.kr
}

PER-ARNT-SIM (bHLH-PAS) domain protein that consists of HIF- $1 \alpha$ and HIF-1 $\beta$ subunits. HIF- $1 \beta$ can dimerize with several different bHLH-PAS protein, whereas HIF- $1 \alpha$ is the specific and $\mathrm{O}_{2}$-regulated subunit of HIF-1 that determines its biological activity. The heterodimer can then bind to hypoxic response elements (HRE) in cytokine gene such as erythropoietin, vascular endothelial growth factor and increase their expression (Wang and Semenza, 1995; Semenza, 2004).

Recently overexpression of HIF- $1 \alpha$ has been demonstrated under normoxic conditions (Qian et 
al., 2004; Shi et al., 2005). In our previous study, HIF-1 was activated by PMA + A23187. A number of studies have confirmed the role of phosphorylation by extracellular signal-regulated kinase (ERK) pathways in the regulation of HIF-1 $\alpha$ expression and/or stabilization and of HIF-1 transactivity (Mottet et al., 2002; Qian et al., 2004).

Human mast cells produce cytokines in response to PMA and the calcium ionophore A23187 (Queralt et al., 2000). We have shown that mast cells synergistically response to PMA + A23187 for producing cytokines. PMA + A23187 treated-HMC-1 cells is a useful in vitro model system for studying multifunctional effects of immune and inflammation reactions (Hosoda et al., 2002).

Panax ginseng (PG), which is native to Korea, China, and Russia, has been an important herbal remedy in traditional oriental medicine for thousands of years. PG is used primarily to improve psychologic function, exercise performance, immune function, and conditions associated with diabetes. There are extensive reports which have determined that ginseng has many pharmacological effects on the immune, cardiovascular, endocrine, and central nervous systems (Nah et al., 1995; Attele et al., 1999). Anti-inflammatory and anti-tumer effect of ginseng has also been found (Park et al., 2004; Wang et al., 2006). However, despite the various reported functions of ginseng, no studies have yet reported the effects of HIF- $1 \alpha$.

In the present study, we investigated the effect of PG on mast cell-mediated inflammatory reaction. We found that PG inhibited HIF-1 $\alpha$ activation and the inflammatory cytokine production via blocking ERK activation.

\section{MATERIALS AND METHODS}

\section{Reagents and chemicals}

Fetal bovine serum, Iscove's Modified Dulbecco's Medium (IMDM), ampicillin and streptomycin were purchased from GIBCO BRL, USA. 3-(4,5dimethylthiazol-2-yl)-2,5-diphenyltetrazolium bromide (MTT), phorbol myristate acetate (PMA), A23187, and 2'-AZINO-bis (3-ethylbenzithiazoline6-sulfonic acid) tablets substrate (ABTS) were purchased from Sigma (St. Louis, MO, USA). Human recombinant (r) IL-1 $\beta$, IL- 6 , TNF- $\alpha$, and VEGF purified anti-human IL-1 $\beta$, IL-6, TNF- $\alpha$, and VEGF, and biotin conjugated anti-human IL-1 $\beta$, IL-6, TNF- $\alpha$, and VEGF antibodies were purchased from R \& D system Inc, USA. HIF-1a antibody was purchased from Santa Cruz Biotechnology (Santacruz, CA, USA).

\section{Preparation of PG water extract}

We pulverized Panax ginseng (Araliaceae). The powdered Panax ginseng $(100 \mathrm{mg}$ ) was extracted with distilled water $(2 \mathrm{ml})$ for $24 \mathrm{~h}$. And then water extract was filtered by $0.22 \mu \mathrm{m}$ syringe filter. It was diluted decouple with distilled water. The PG was obtained from Oriental drug store, Daehak Oriental Drugstore (Iksan, Republic of Korea) and classified and identified by local experts. Their voucher specimens have been deposited at the Herbarium at the college of Pharmacy, Wonkwang University. As shown in Table 1, ginsenosides of PG were identified.

\section{Ginsenoside analysis by HPLC}

For HPLC analysis, ginsenosides were extracted as the method described by Samukawa et al. (1995) One $g$ of milled powder of freeze-dried adventitious

Table 1. Composition of PG water extract used in this study

\begin{tabular}{ccc}
\hline Types of ginsenosides & Rate $(\%)$ & $\mathrm{g} / \mathrm{ml}$ \\
\hline $\mathrm{Rb}^{\mathrm{a}}$ & 27.74 & 866.0 \\
$\mathrm{Rb}^{\mathrm{a}}$ & 22.00 & 686.7 \\
$\mathrm{Rc}^{\mathrm{a}}$ & 22.27 & 695.1 \\
$\mathrm{Rd}^{\mathrm{a}}$ & 10.36 & 323.5 \\
$\mathrm{Re}^{\mathrm{b}}$ & 6.55 & 204.6 \\
$\mathrm{Rf}^{\mathrm{b}}$ & 5.73 & 178.7 \\
$\mathrm{Rg}^{\mathrm{b}}$ & 5.35 & 167.1 \\
total & 100.00 & $3,121.7$ \\
$\mathrm{PD} / \mathrm{PT}$ & 4.74 & \\
\hline
\end{tabular}

${ }^{\mathrm{a}}$ Protophnaxadiol (PPD); ${ }^{\mathrm{b}}$ Protopanaxatriol (PPT). 
roots was soaked in $80 \% \mathrm{MeOH}$ at $60{ }^{\circ} \mathrm{C}$. After liquid was evaporated, the residue was dissolved in $\mathrm{H}_{2} \mathrm{O}$ and washed twice, followed by extraction with $\mathrm{H}_{2} \mathrm{O}$-saturated n-butanol. The butanol layer was then evaporated to produce saponin fraction. Each sample was dissolved in $\mathrm{EtOH}$, and then filtrated with SepPak C-18 Cartridge (Waters, USA). The HPLC separation was performed on a NovaPak C18 column $(4 \mu \mathrm{m}, 3.9 \times 150 \mathrm{~mm}$, Waters, USA), applying the following gradient system: $0 \mathrm{~min}, 100 \%$ acetonitrile; $10 \mathrm{~min}, 75 \%$ acetonitrile and $25 \%$ water; $25 \mathrm{~min}, 67 \%$ acetonitrile and $37 \%$ water. Flow rate of the mobile phase was $1.2 \mathrm{ml} / \mathrm{min}$, and ginsenosides were monitored at a wavelength of $202 \mathrm{~nm}$. Each ginsenoside was compared with the authentic ginsenoside purchased from ChromaDex Inc (california, USA). Quantitative analysis was performed on a one-point curve method using external standards of authentic ginsenosides.

\section{Western blot analysis}

Cell extracts were prepared by detergent lysis procedure. Cells $\left(5 \times 10^{6}\right.$ cells $)$ were harvested, washed once with PBS, and resuspended in lysis buffer. Samples were vortexed for lysis for a few seconds every $15 \mathrm{~min}$ at $4^{\circ} \mathrm{C}$ for $1 \mathrm{~h}$ and centrifuged at $15,000 \times \mathrm{g}$ for $5 \mathrm{~min}$ at $4^{\circ} \mathrm{C}$. Supernatants were assayed. Samples were heated at $95^{\circ} \mathrm{C}$ for $5 \mathrm{~min}$, and briefly cooled on ice. Following the centrifugation at $15,000 \times \mathrm{g}$ for $5 \mathrm{~min}, 50 \mathrm{ml}$ aliquots were resolved by $12 \%$ SDS-PAGE. Resolved proteins were electrotransferred $150 \mathrm{~min}$ to nitrocellulose membranes in $25 \mathrm{mM}$ Tris, $\mathrm{pH} 8.5,200 \mathrm{mM}$ glycin, 20\% methanol at $300 \mathrm{~mA}$. Blots were blocked for at least $2 \mathrm{~h}$ with $5 \%$ nonfat dry milk. Protein levels were analyzed essentially according to the manufacturer's instructions.

\section{Nuclear protein extraction}

After cell activation for the times indicated, $1 \times 10^{7}$ cells were washed in $1 \mathrm{ml}$ of ice-cold PBS, centrifuged at $1000 \times g$ for $5 \mathrm{~min}$, resuspended in $400 \mathrm{ml}$ of ice-cold hypotonic buffer (0.01 M HEPES/
$\mathrm{KOH}, 2 \mathrm{mM} \mathrm{MgCl}, 0.1 \mathrm{mM}$ EDTA, $10 \mathrm{mM} \mathrm{KCl}$, $1 \mathrm{mM}$ DTT, $0.5 \mathrm{mM}$ PMSF, pH 7.9), left on ice for $10 \mathrm{~min}$, vortexed, and centrifuged at 15,000 $\times \mathrm{g}$ for $30 \mathrm{~s}$. Pelleted nuclei were gently resuspended in 50 $\mathrm{ml}$ of ice-cold saline buffer $(50 \mathrm{mM}$ HEPES/KOH, $50 \mathrm{mM} \mathrm{KCl}, 0.3 \mathrm{M} \mathrm{NaCl}, 0.1 \mathrm{mM}$ EDTA, $10 \%$ glycerol, $1 \mathrm{mM}$ DTT, $0.5 \mathrm{mM}$ PMSF, $\mathrm{pH}$ 7.9), left on ice for $20 \mathrm{~min}$, vortexed, and centrifuged at $15,000 \times g$ for $5 \mathrm{~min}$ at $4{ }^{\circ} \mathrm{C}$. Aliquots of the supernatant that contain nuclear proteins were frozen in liquid nitrogen and stored at $-70^{\circ} \mathrm{C}$. Protein was determined using a bicinchoninic acid (Sigma. St. Louis, MO, USA).

\section{MTT assay}

Cell aliquots $\left(3 \times 10^{5}\right)$ were seeded in microplate wells and incubated with $20 \mathrm{ml}$ of a MTT solution ( $5 \mathrm{mg} / \mathrm{ml}$ ) for $4 \mathrm{~h}$ at $37^{\circ} \mathrm{C}$ under $5 \% \mathrm{CO}_{2}$ and $95 \%$ air. Consecutively, $250 \mathrm{ml}$ of DMSO was added to extract the MTT formazan and an automatic microplate reader read the absorbance of each well at $540 \mathrm{~nm}$.

\section{Assay of IL-1 $\beta$, IL-6, TNF- $\alpha$, and VEGF secretion} IL-1 $\beta$, IL-6, TNF- $\alpha$, and VEGF secretion were measured by a modified ELISA. The ELISA was devised by coating 96 well plates of human monoclonal antibody with specificity for IL-1 $\beta$, IL-6, TNF- $\alpha$, and VEGF. Before subsequent steps in the assay, coated plates were washed with PBS containing $0.5 \%$ tween-20 (PBST). All reagents used in this assay were incubated for $2 \mathrm{~h}$ at $37^{\circ} \mathrm{C}$. Recombinant IL-1 $\beta$, IL-6, TNF- $\alpha$, and VEGF was diluted and used as a standard. Serial dilutions starting from $5 \mathrm{ng} / \mathrm{ml}$ were used to establish the standard curve. Assay plates were exposed sequentially to biotinylated human IL-1 $\beta$, IL-6, TNF- $\alpha$, and VEGF, and avidine peroxidase, and ABTS substrate solution containing $30 \% \mathrm{H}_{2} \mathrm{O}_{2}$. The plates were read at $405 \mathrm{~nm}$.

\section{Statistical analysis of data}

The experiments shown are a summary of the data from at least-three experiments and are presented 
as the mean \pm S.E.M. Statistical evaluation of the results was performed by ANOVA with Tukey post hoc test. The results were considered significant at a value of $P<0.05$.

\section{RESULTS}

\section{Effect of PG on PMA+A23187-induced HIF-1 activation}

The expression level of HIF-1a in nucleus of HMC1 cells was examined by Western blot analysis. In PMA+A23187-stimulated cells, the expression level of HIF- $1 \alpha$ increased in the nucleus. However, the expression level of HIF-1 $\alpha$ in nucleus was decreased by treatment of PG 5, 50, or $500 \mathrm{~g} / \mathrm{ml}$ (Fig. 1). We performed low concentration $(0.5 \mathrm{~g} / \mathrm{ml} \mathrm{PG})$. But low concentration did not inhibit HIF-1 $\alpha$ expression (data not shown). $\beta$-actin expression level was not changed by any treatment in nuclear extract.

\section{Effect of PG on PMA+A23187-induced VEGF production}

Because VEGF is one of the HIF-1 target genes, we determined whether PG can modulate PMA+ A23187-induced VEGF production. To determine whether PG can modulate PMA+A23187-induced VEGF production, the cells were pretreated with various concentrations of $\mathrm{PG}$ for $30 \mathrm{~min}$ prior to PMA+A23187 stimulation. Culture supernatants were assayed for VEGF protein levels by using ELISA method. The PG did not affect VEGF production in

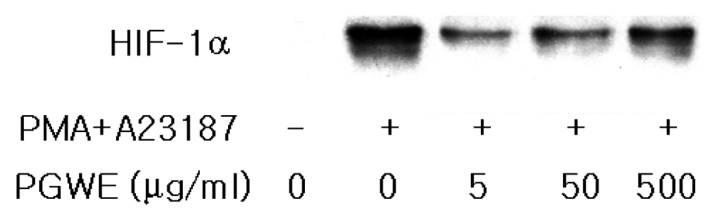

Fig. 1. Effect of PG on the PMA + A23187-induced HIF-1 $\alpha$ activation. HMC- 1 cells $\left(5 \times 10^{6}\right)$ were treated with PG $(5500 \mathrm{~g} / \mathrm{ml})$ for $30 \mathrm{~min}$ prior to the stimulation of PMA $(50 \mathrm{nM})+\mathrm{A} 23187(1 \mathrm{M})$ for $4 \mathrm{~h}$. Nuclear protein $(50 \mathrm{~g})$ was prepared and analyzed for HIF-1 $\alpha$ by Western blotting as described in the experimental procedures. Results show a representative of three experiments with similar observations.

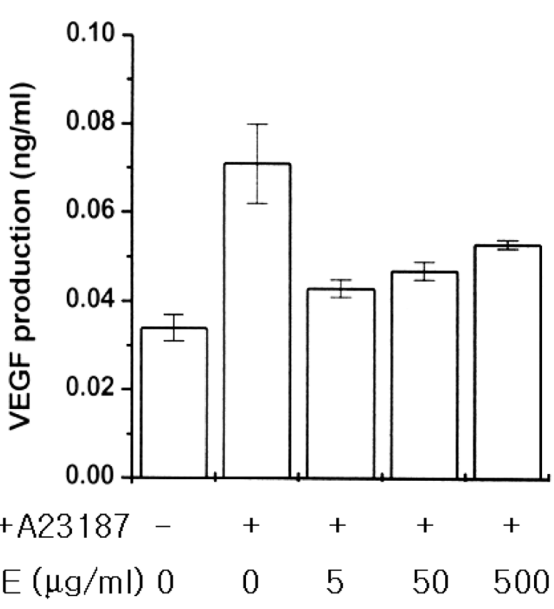

Fig. 2. Effect of PG on PMA + A23187-induced VEGF production. HMC-1 cells $\left(3 \times 10^{5}\right)$ were pretreated with indicated concentrations of PG for $30 \mathrm{~min}$ and then treated the PMA $(50 \mathrm{nM})+\mathrm{A} 23187(1 \mathrm{M})$ for $24 \mathrm{~h}$. VEGF concentration was measured in cell supernatants using the ELISA method. Each bar represents the mean \pm S.E.M. from three separate experiments.

the absence of PMA+A23187 (data not shown). However, in PMA+A23187-stimulated cells, VEGF production was decreased by treatment of PG (Fig. 2).

\section{Effect of PG on ERK activation}

Evidence suggests that the thranscriptional activity of HIF-1 is modulated by phosphorylation. The ERK mitogen-activated protein kinase (MAPKs) catalyzes HIF-1 $\alpha$ phosphorylation (Haddad and Harb, 2005; Shi et al., 2005). Many studies reported that MAPKs regulate the cytokine production and

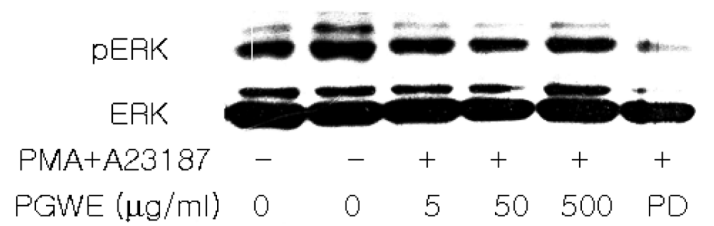

Fig. 3. Effect of PG on the PMA + A23187-induced ERK phosphorylation. HMC-1 cells $\left(2 \times 10^{6}\right)$ were pretreated with PG $(5500 \mathrm{~g} / \mathrm{ml})$ and PD98059 $(20 \mathrm{M})$ for $30 \mathrm{~min}$ and then treated with PMA (50 nM) + A23187 (1 M) for $15 \mathrm{~min}$. Total protein $(50 \mathrm{~g})$ was prepared and analyzed for anti-phospho-ERK Abs/ anti-total ERK Abs by Western blotting as described in the experimental procedures. These experiments have been repeated three times with similar observations. 

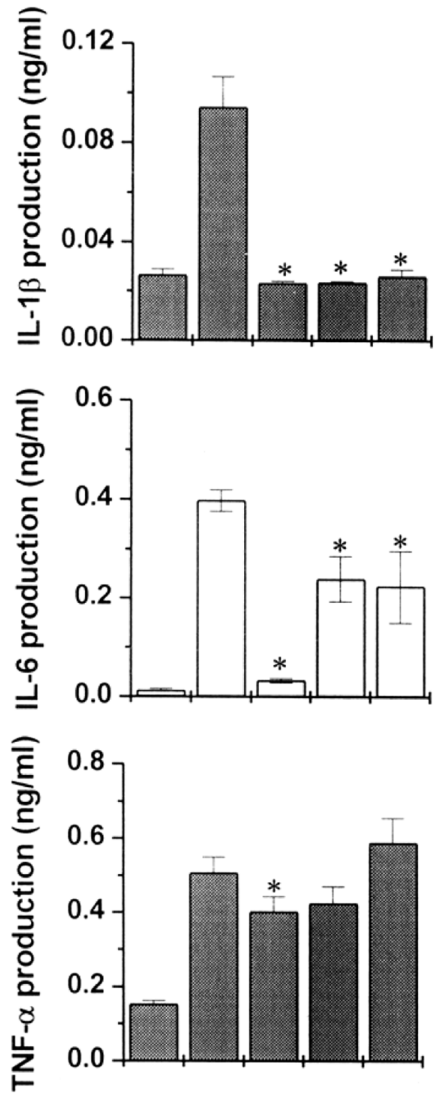

$\mathrm{PMA}+\mathrm{A} 23187-++++$

PGWE $(\mu \mathrm{g} / \mathrm{ml}) \quad 0 \quad 0 \quad 5 \quad 50500$

Fig. 4. Effect of PG on PMA + A23187-induced inflammatory cytokines production. HMC-1 cells $(3 \times$ $10^{5}$ ) were treated with various concentrations of PG for 30 min prior to the addition of PMA $(50 \mathrm{nM})+$ A23187 (1 M), and the cells were further incubated for $8 \mathrm{~h}$. Cytokine concentrations were measured from cell supernatants using ELISA method. Each bar represents the mean \pm S.E.M. from three separate experiments. ${ }^{*} P$ $<0.001$ : compared to PMA + A23187-treated cells without PG.

expression in early event (Acuna-Castillo et al., 2005; Manjula et al., 2006). We previously reported that the phosphorylation of MAPKs (ERK, JNK, p38) induced by PMA+A23187 from $10 \mathrm{~min}$ to $4 \mathrm{~h}$. The level of phosphorylation decreased after $2 \mathrm{~h}$ (Kim et al., 2005). To determine the effect of PG on ERK phosphorylation, Western blot analyses for phospho-ERK/ERK were performed. In this study, we observed that PMA + A23187 rapidly induced phosphorylation of ERK at $15 \mathrm{~min}$, but the pretreatment of various concentrations PG inhibited the phosphorylation level of ERK. PD98059 (Albina et al., 2001). was used positive control (Fig. 3).

\section{Effect of PG on PMA+A23187-induced inflammatory cytokine production in HMC-1 cells}

To determine whether PG can modulate PMA+ A23187-induced inflammatory cytokine production, the cells were pretreated with various concentrations of PG for 30 min prior to PMA + A23187 stimulation for $8 \mathrm{~h}$. Culture supernatants were assayed for IL$1 \beta$, IL-6, and TNF- $\alpha$ protein levels by using ELISA method. The PG did not affect IL-1 $\beta$, IL-6, and TNF- $\alpha$ production in the absence of PMA + A23187 (data not shown). However, in PMA + A23187stimulated cells, IL-1 $\beta$, IL-6, and TNF- $\alpha$ production was significantly decreased by treatment of PG $(P$ $<0.05)$. Inhibition rate of IL-1 $\beta$ was observed to be higher than inhibition rate of IL- 6 and TNF- $\alpha$ (Fig. 4). To test the effect of PG on cytotoxicity, we performed MTT assay in HMC-1 cells. PG did not significantly affect cell viability compared with media control cell viability and had no toxicity on HMC-1 cells (Fig. 5).

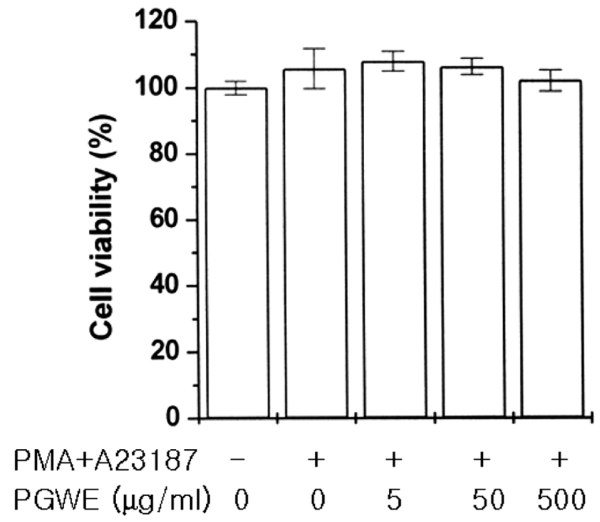

Fig. 5. Effect of PG on cell viability. HMC-1 cells $(3 \times$ $10^{5}$ ) were treated with indicated concentrations of PG for $24 \mathrm{~h}$ absence or presence of PMA $(50 \mathrm{nM})+$ A23187 (1 M). Cell viability was evaluated by MTT assay. The each percentage of viable cells was calculated using $100 \%$ for media control cells. PG did not significantly affect cell viability compared with media control cell viability. 


\section{DISCUSSION}

In this study, we showed that PG regulates HIF-1 activation production in PMA + A23187-stimulated mast cells for the first time. More over, PG inhibited VEGF production, ERK activation, and the inflammatory cytokine production in PMA + A23187-stimulated mast cells.

HIF-1 activity is up-regulated by pro-inflammatory messengers, such as $\mathrm{NO}$, and pro-inflammatory cytokines, such as TNF- $\alpha$, IL-1 $\beta$ (Thornton et al., 2000; Sandau et al., 2001). Jung et al. (2003) reported that IL-1 $\beta$ up-regulated HIF-1 $\alpha$ via an NF-kB/COX-2 pathway. Another reported that HIF-1 $\alpha$ expression is strongly increased in inflammatory cells from wounds (Albina et al., 2001). Taken together, these data implicate HIF-1 as an important mediator of inflammatory reaction. In this study, PG inhibited PMA + A23187-induced HIF-1a expression. Hence, it is hypothesized that PG might act as a potent HIF-1 $\alpha$ inhibitor on the mast cell activation induced by PMA + A23187. It has been well known that HIF-1 is one of the major transcriptional activators of VEGF gene (Semenza, 2004). In this study, we showed that PG suppressed production of the VEGF induced by PMA + A23187 in HMC-1.

Pages et al. (2000) demonstrated that ERK stoichiometrically phosphorylated HIF-1 $\alpha$ in vitro and that HIF-1-dependent VEGF gene expression was strongly enhanced by the exclusive activation of ERK. Treatment of the HMC-1 with PMA + A23187 resulted in ERK phosphorylation. The increased VEGF production in the culture media was reduced by PD98059 (data not shown). It indicated that PD98059 prevents not only the ERK activity, but also the production of VEGF induced by PMA + A23187 in HMC-1. In many other cell lines, the PD98059 does not influence the stability of HIF-1, but it can reduce the transactivation potential of HIF-1 (Hur et al., 2001). However, recent studied reported that PD98059 directly suppressed HIF-1 $\alpha$ protein expression (Qian et al., 2004; Frede et al., 2006). These results suggest that ERK-mediated regulation of the HIF-1 $\alpha$ pathway might be cell-type specific. In this study, we found that PG blocked ERK activation by PMA + A23187 in HMC-1. These data demonstrate that PG might inhibit HIF-1 $\alpha$ activation through suppression of ERK phosphorylation in HMC-1.

As mast cells contain potent mediators including multifunctional cytokines, they contribute to the pathogenesis of chronic inflammatory disease (Anderson et al., 1997). Therefore, mast cell activation significantly contributes to the initiation of exacerbation of inflammation. Cytokines, such as IL-1 $\beta$, IL-6, and TNF- $\alpha$ have been clearly involved in the inflammatory process (Nishimoto, 2005). Recently, anti-TNF therapy has defined a molecular target and new approach for treating inflammatory disorders (Keystone, 2001; Taylor, 2001). It has been reported that ginsenoside $\mathrm{Rb}_{1}$ inhibited LPSinduced IL- 6 and TNF- $\alpha$ production in in vitro and in vivo (Cho et al., 2001; Smolinski and Pestka, 2003). In this study, we showed that PG inhibited the PMA + A23187-induced IL-1 $\beta$, IL-6, and TNF- $\alpha$ production. In our previous study, we also showed that PD98059 inhibited IL-1 $\beta$, IL-6, and TNF- $\alpha$ production (Kim et al., 2005). Therefore, we can presuppose that PG may inhibit cytokine production through inhibition of ERK phosphorylarion.

\section{ACKNOWLEDGEMENTS}

This work was supported by the Korea Rresearch Foundation grant of the Korean Government Ministry of Education and Human Resource Development (MOEHRO), KRF-2004-042-E00160.

\section{REFERENCES}

Acuna-Castillo C, Aravena M, Leiva-Salcedo E, Perez V, Gomez C, Sabaj V, Nishimura S, Perez C, Colombo A, Walter R, Sierra F. (2005) T-kininogen, a cystatinlike molecule, inhibits ERK-dependent lymphocyte proliferation. Mech. Ageing 126, 1284-1291.

Albina JE, Mastrofrancesco B, Vessella JA, Louis CA, Henry WLJr, Reichner JS. (2001) HIF-1 expression 
in healing wounds: HIF-1alpha induction in primary inflammatory cells by TNF-alpha. Am. J. Physiol. Cell Physiol. 281, 1971-1977.

Anderson DF, MacLeod JD, Baddeley SM, Bacon AS, McGill JI, Holgate ST, Roche WR. (1997) Seasonal allergic conjunctivitis is accompanied by increased mast cell numbers in the absence of leucocyte infiltration. Clin. Exp. Allergy 27, 1060-1066.

Attele AS, Wu JA, Yuan CS. (1999) Ginseng pharmacology: multiple constituents and multiple actions. Biochem. Pharmacol. 58, 1685-1693.

Cho JY, Yoo ES, Baik KU, Park MH, Han BH. (2001) In vitro inhibitory effect of protopanaxadiol ginsenosides on tumor necrosis factor (TNF)-alpha production and its modulation by known TNF-alpha antagonists. Planta Med. 67, 213-218.

Frede S, Stockmann C, Freitag P, Fandrey J. (2006) Bacterial lipopolysaccharide induces HIF-1 activation in human monocytes via p44/42 MAPK and NFkappaB. Biochem. J. 396, 517-527.

Haddad JJ, Harb HL. (2005) Cytokines and the regulation of hypoxia-inducible factor (HIF)-1alpha. Int. Immunopharmacol. 5, 461-483.

Hosoda M, Yamaya M, Suzuki T, Yamada N, Kamanaka M, Sekizawa K, Butterfield J H, Watanabe T, Nishimura H, Sasaki H. (2002) Effects of rhinovirus infection on histamine and cytokine production by cell lines from human mast cells and basophils. J. Immunol. 169, 1482-1491.

Hur E, Chang KY, Lee E, Lee SK, Park H. (2001) Mitogen-activated protein kinase kinase inhibitor PD98059 blocks the trans-activation but not the stabilization or DNA binding ability of hypoxiainducible factor-1alpha. Mol. Pharmacol. 59, 1216-1224.

Jung YJ, Isaacs JS, Lee S, Trepel J, Neckers L. (2003) IL1beta-mediated up-regulation of HIF-1alpha via an NFkappaB/COX-2 pathway identifies HIF-1 as a critical link between inflammation and oncogenesis. FASEB J. 17, 2115-2117.

Keystone EC. (2001) Tumor necrosis factor-alpha blockade in the treatment of rheumatoid arthritis. Rheum. Dis. Clin. North Am. 27, 427-443.

Kim SJ, Jeong HJ, Choi IY, Lee KM, Park RK, Hong SH, Kim HM. (2005) Cyclooxygenase-2 inhibitor SC-236 [4-[5-(4-chlorophenyl)-3-(trifluoromethyl)-1pyrazol-1-1] benzenesulfonamide] suppresses nuclear factor-kappaB activation and phosphorylation of p38 mitogen-activated protein kinase, extracellular signal-regulated kinase, and c-Jun N-terminal kinase in human mast cell line cells. J. Pharmacol. Exp. Ther. 314, 27-34.

Manjula N, Gayathri B, Vinaykumar KS, Shankernarayanan $\mathrm{NP}$, Vishwakarma RA, Balakrishnan A. (2006) Inhibition of MAP kinases by crude extract and pure compound isolated from Commiphora mukul leads to down regulation of TNF-alpha, IL1beta and IL-2. Int. Immunopharmacol. 6, 122-132.

Mottet D, Michel G, Renard P, Ninane N, Raes M, Michiels C. (2002) ERK and calcium in activation of HIF-1. Ann. N.Y. Acad. Sci. 973, 448-453.

Nah SY, Park HJ, McCleskey EW. (1995) A trace component of ginseng that inhibits $\mathrm{Ca}^{2+}$ channels through a pertussis toxin-sensitive $G$ protein. Proc. Nati. Acad. Sci. USA 92, 8739-8743.

Nishimoto N. (2005) Cytokine signal regulation and autoimmune disorders. Autoimmunity 38, 359-367.

Pages G, Milanini J, Richard DE, Berra E, Gothie E, Vinals F, Pouyssequr J. (2000) Signaling angiogenesis via p42/p44 MAP kinase cascade. Ann. N.Y. Acad. Sci. 902, 187-200.

Park EK, Choo MK, Han MJ, Kim DH. (2004) Ginsenoside Rh1 possesses antiallergic and antiinflammatory activities. Int. Arch. Allergy Immunol. 133, 113-120.

Qian D, Lin HY, Wang HM, Zhang X, Liu DL, Li QL, Zhu C. (2004) Normoxic induction of the hypoxicinducible factor- 1 alpha by interleukin- 1 beta involves the extracellular signal-regulated kinase $1 / 2$ pathway in normal human cytotrophoblast cells. Biol. Reprod. 70, 1822-1827.

Queralt M, Brazis P, Merlos M, de Mora F, Puigdemont A. (2000) In vitro inhibitory effect of rupatadine on histamine and TNF-alpha release from dispersed canine skin mast cells and the human mast cell line HMC-1. Inflamm. Res. 49, 355-360.

Samukawa K, Yamashita H, Matsuda H, Kubo M. (1995) Simultaneous analysis of ginsenosides of various ginseng radix by HPLC. Yakugaku Zasshi 115, 241-249.

Sandau KB, Zhou J, Kietzmann T, Brune B. (2001) Regulation of the hypoxia-inducible factor 1alpha by the inflammatory mediators nitric oxide and tumor necrosis factor-alpha in contrast to desferroxamine and phenylarsine oxide. J. Biol. Chem. 276, 39805- 
39811.

Semenza GL. (2004) Hydroxylation of HIF-1: oxygen sensing at the molecular level. Physiology 19, 176182.

Shi YH, Wang YX, Bingle L, Gong LH, Heng WJ, Li Y, Fang WG. (2005) In vitro study of HIF-1 activation and VEGF release by bFGF in the T47D breast cancer cell line under normoxic conditions: involvement of PI-3K/Akt and MEK1/ERK pathways. J. Pathol. 205, 530-536.

Smolinski AT, Pestka JJ. (2003) Modulation of lipopolysaccharide-induced proinflammatory cytokine production in vitro and in vivo by the herbal constituents apigenin (chamomile), ginsenoside $\mathrm{Rb}(1)$ (ginseng) and parthenolide (feverfew). Food Chem. Toxicol. 41,
1381-1390.

Taylor PC. (2001) Anti-TNF therapy for rheumatoid arthritis and other inflammatory diseases. Mol. Biotechnol. 19, 153-168.

Thornton RD, Lane P, Borghaei RC, Pease EA, Caro J, Mochan E. (2000) Interleukin 1 induces hypoxiainducible factor 1 in human gingival and synovial fibroblasts. Biochem. J. 350, 307-312.

Wang GL, Semenza GL. (1995) Purification and characterization of hypoxia-inducible factor 1 . J. Biol. Chem. 270, 1230-1237.

Wang Z, Zheng Q, Liu K, Li G, Zheng R. (2006) Ginsenoside $\mathrm{Rh}(2)$ enhances antitumour activity and decreases genotoxic effect of cyclophosphamide. Basic Clin. Pharmacol. Toxicol. 98, 411-415. 